The water is clammed up, and a sloping channel left; at the bottom a cloth is spread, kept down by stones so as to make the bottom uneven; one man sprinkles the auriferous earth over the channel, and another flushes the channel by means of a leather bag, the pieces of gold fall into the inequalities and are easily collected in the cloth by lifting up the stones. The yield is large, nuggets of two pounds weight are found; the gold sells on the spot at rather less than thirty rupees per ounce. A gold commissioner or "sarpon" superintends all the goldfields, a string of which extends along the northern watershed of the Brahmaputra, from Lhasa to Rudok. Each field has a chief or master, but anyone may dig who pays the annual licence-fee of one sarapoo or two-fifths of an ounce.

The curious posture for sleeping, universal among the Thibetans, was observed here. They invariably draw their knees close up to their heads, and rest on their knees and elbows, huddling every scrap of clothing they can muster on their backs; the richer rest thus on a mattress rising towards the head. The poorer avail themselves of a suitable slope on the hill side, or pile stones and earth to a convenient height. This position is most probably adopted in order to secure as much warmth as possible for the abdomen, the thighs pressing against it and excluding the air:

The gold-diggers recreate themselves with tobacco smoked in iron pipes, and, notwithstanding the hardships of their laborious toil, seem very merry, singing songs in chorus, in which the women and children join.

LETTERS TO THE EDITOR
[The Editor does not hold himself responsible for opinions expressed
by his Correspondents.]
Lectures to Ladies

Your corresponclent " $M$." in her letter, which appeared in NATURE No. IV., on the subject of the exclusion of teachers from the lectures to ladies at South Kensington and University College, is scarcely just in her remark that " at University College they don't pretend to care for such an audience." The committee of the Lducational Association certainly do not pretend to care for governesses, but give a more substantial proof of their care by adnitting them on reduced terms.

All honour to "M." for advocating the clains of governesses; but has she not, in her desire for improving their mental faculties, omitted to talie an account of their physical powers? To the question, therefore, which she has propounded-" How can any one who is hard at work all day go to a lecture in the forenoon ?"-I am tempted to reply, in the American fashion, by asking another: "How can any one who is harl at work all day go to a lecture in the evening?" There is also the minor consideration that the hire of a lecture-room (the majority of our classes being held in a hired room) for the evening is nearly twice that of a room for the morning, so that it would be a somewhat hazarclous experiment to institute evening classes on the chance of ladies who are engaged in teaching all day attending in sufficient numbers to pay the rent.

In conclusion, I hope that if "M." can spare a feir minutes of her valuable time some forenoon, she will look in at one of our lectures; and if she sees, or rather hears, anyone answering the description of "Lacly Barbara, who sneers aloud," I will use my utmost endeavours to get up an evening class for "M." even thougl she should be the only pupil.

'The Hon. Sec. of the Ladifs' Educational AsSOCIATION, LONDON

\section{Chrysophanus Dispar}

You ask for information about Chrysophanns Dispar. The statement that it has been met with in Kerry is not in itself improbable, and entomologists will be interested in having it confirmed; but when we find it said in the same paragraph that the insect is not uncommon in England, it will be received with doubt. $C$. Dispar has hitherto been found in only one locality in these islands, the neighbourhood of the fens formerly surrounding Whittlesea Mere. Other localities appenx in works on entomology, but have nercr been authenticated.
Owing partly to the drainage of the fens, and partly to the indefatigable efforts of dealers and other collectors, the insect has been quite extinct, I believe, for nearly twenty years.

Of late years the subdivision of species in entomology as well as in other departments of Natural History has been somewhat checked. What formerly appeared as those distinct species of Polyommatzus, in our books of British Butterflies, under the names of Agestis, Artaxerxes, aud Salmacis, are now all referred to the first-named species. Agestis is absent where Salmacis is found, and both where Artaxerxes is found, and the variety is referred to the difference of latitude. In the same way entomologists no longer recognise any specific distinction between C. Dispar and C. Hippothoe, widelyspread continental species. I possess a fine series of C. Dispar reared from larve taken in the year 1846 . The spot in which they were found is close to the Holme station, 69 miles from London on the Great Northern Railway. They fed exclusively on the common water dock (Rumex Paluastris). It is a curious illustration of the obscure causes which regulate the geographical range of species, that though the plant is abundant in the whole range of fen country, and generally throughout England, the butterfly was always confined to that immediate neighbourhood.

C. Virsaureg was introduced into catalogues of British Lepidoptera on the authority of clealers, but its claims to be a British species were never authenticated.

Eton, Windsor.

C. W. D.

\section{The Brighton Aquarium}

WOULD it be unduly troubling you were I to ask you to inform me, through the medium of the columns of NATURE, if the much-talked-of Brighton Aquarium is renlly to be "started"?

\section{H. H. MотT}

The Cloaca Maxima

WiLl you parclon me for asking a question which probably I ought to be able to answer myself? Mr. Corfield, in his interesting comparison of the hygienic performances of the ancients and ourselves, mentions the well-known Cloaca Maxima as one of the great glories of the Romans. Can he tell us how they got the sewage into it? I presume the invention of Bramah was not known in those times, and I was a little disappointed in not finding in his able paper a solution of a mystery which has puzzled me since my childhood. What did the Romans want with a Cloaca Maxima, and how did they use it?

Dec. rrth.

\section{Lightning in a Clear Sky}

THE following extract from the "Life of Charlemagne," by Eginhard, a contemporary, may be interesting to C. W. D. "Cum Carolus imperator nitimam in Saxoniam expeditionem contra Godefridum, regem Danorum, ageret, quadam die, cum, ante exortum solis, castris egressus, iter agere coepisset, vidlit repente delapsam cœlitus cum ingenti lumine facem a dextra in sinistram per serenum aera transcurrere; cunctisque hoc signtm, quicl portenderet, admirantibus, subito equus quem sedebat, capite deorsum merso, decidit, eumg̨ue tam graviter ad terram clisit, ut fibula sagi rupta balteoque gladii dissipato, a festinantibus qui aderant ministris exarmatus non sine adminiculo levaretur, Jaculum etiam quod tunc forte manu tenebat, ita elapsum est ut riginti vel eo amplius pectum spatio longe jaceret." J.M. W.

\section{NOTES}

IT is stated that the Council of the British Association for the Advancement of Science have determined to ask the permission of the Lord President of the Council to appear before him as a Deputation, to urge upon the Government the need of a Royal Commission to inquire into the Present State of Science in England. We may congratulate ourselves that in Lord De Grey we have a Minister whose well-known large and scientific sympathies ensure a careful consideration of the important proposition to be laid before him.

MOST of our readers know ere this that the Government has determined not to fill up the appointment of the Mastership of the Mint vacant by the death of the lamented Graham. The duties are to be performed by...Mr. Freemantle, who deserves all 